\title{
Differential Staining of Cultured Bone Marrow Cell Chromosomes of Rana pipiens
}

\author{
Joseph N. Manago, Frank L. Spina and William H. Beckert ${ }^{1}$ \\ Department of Biological Sciences, St. John's University, New York 11439, U.S.A.
}

Received January 6, 1979

Chromosome banding has been widely utilized to identify homologous chromosomes more precisely, and also to analyze genetic rearrangements apropos evolutionary speciation and medical genetics. Q-banding employs alkylating agents, such as quinacrine hydrochloride and quinacrine mustard (Caspersson et al. 1968, Caspersson et al. 1969, Caspersson et al. $1970 \mathrm{a}, \mathrm{b}$, Miller et al. 1971). C-banding which identifies heterochromatic DNA has been reported (Arrighi and Hsu 1971, Sumner 1972, Gallagher et al. 1973, Ruiz and Becak 1976). G-banding produces distinct bands along the entire chromosome with various post-fixation treatments followed by Giemsa staining. G-banding has been elicited through post-fixation treatment with alkaline-saline (Drets and Shaw 1971, Schnedl 1971), acid-saline (Gagne et al. 1971, Sumner et al. 1971), Giemsa 9 staining (Patil et al., 1971), pronase (Dutrillaux et al. 1971), trypsin (Wang and Federoff 1972, Seabright 1972, Sun et al. 1974), urea (Shiraishi and Yosida 1972), potassium permanganate (Utakoji 1972, Matsukuma and Utakoji 1976), and caesium chloride (Meisner et al. 1973). R-banded chromosomes, which show a pattern the opposite of G-banding, have also been described (Dutrillaux and Lejeune 1971, Verma and Lubs 1975, 1976). F-banding has been produced through the use of a post-fixation treatment together with the standard Feulgen reaction (Rodman and Tahiliani 1973, Rodman 1974). Pre-fixation treatment of chromosomes with agents such as ethidium bromide have also induced chromosome cross-banding (Hsu et al. 1973). Most of the above banding studies involved mammalian chromosomes, with emphasis on those of humans.

Banding of amphibian chromosomes has also been reported. Utilizing the squash method, epithelial cell chromosomes of Pleurodeles waltlii were stained differentially with Giemsa 9 (Labrousse et al. 1972). Q-banding has also been utilized to study the tail cell chromosomes of $P$. waltii (Bailly 1972, 1976). Giemsa 9 and Q-banding patterns of $P$. waltlii chromosomes have been compared (Bailly et al. 1973). Other banding studies involve members of the genus Triturus. Cbanding patterns of squash preparations of $T$. vulgaris meridionalis and $T$. italicus have been reported (Nardi et al. 1973). C-banding patterns have also been described for $T$. cristatus and $T$. marmoratus (Mancino et al. 1973). G-, C-, and Q-banding patterns were reported for $T$. alpestris apuanus, T. cristatus carnifex, $T$. marmoratus marmoratus, $T$. italicus, and $T$. vulgaris meridionalis (Ragghianti et al. 1973). This latter work involved the production of $G$-bands according to

1 Address all correspondence. 
Drets and Shaw (1971), Dutrillaux (1971), Sumner et al. (1971), and Schnedl (1971). C-bands have also been reported on the lampbrush chromosomes of $T$. marmoratus (Batistoni et al. 1974). The chromosomes of $T$. cristatus have been studied with C- and G-banding (Rudak and Callan 1976). The above amphibian studies involved members of the order Urodela.

Although earlier work on banding in Amphibia has been largely confined to the members of the order Urodela, more recently studies have been reported for banding in the Anura. G-banding of certain select chromosomes has been reported for chromosomes of cultured cells of Xenopus muelleri (Stock and Mengden 1975). Extensive work on C-banded chromosomes has been reported for numerous species of Anura. C-banding has been demonstrated for the diploid and tetraploid species of Odontophrynus americanus and O. cultripes (Ruiz and Becak 1976). Extensive studies in 22 species of bufonids and hylids utilizing Q- and C-banding methods have delineated the distribution and quantity of constitutive heterochromatin and nucleolus organizer regions (Schmid 1978a). However, in euchromatic regions and metaphase chromosomes neither G- nor Q- bands have been found (Schmid 1978). Data have been presented on the constitutive heterochromatin of Rana ridibunda (Raicu and Geormăneanu 1977), and on constitutive heterochromatin and nucleolus organizer regions in 12 species of the families Ranidae, Microhylidae, and Rhacophoridae (Schmid 1978b) with demonstrations of centric heterochromatin, and telomeric and interstitial C-bands. However, Q- and G-bands have not been demonstrated in metaphase chromosomes (Raicu and Geormăneanu 1977, Schmid 1978b).

\section{Materials and methods}

Specimens of the North American leopard frog, Rana pipiens, were obtained from Champlain Biological Service, Glen Gardner, New Jersey. The medium, medium additives, and balanced salt solutions were purchased form Grand Island Biological Supply Company, Grand Island, New York.

Bone marrow cultures were established according to the method of Beckert and Doyle (1967). The frogs were sacrificed by pithing or decerebration, and then bathed in 70\% ethanol, thimerosal tincture, 1: 1000 (Eli Lilly \& Co., Indianapolis, Indiana), and $70 \%$ ethanol, respectively. The dissections were carried out in a hood utilizing aseptic technique. The femurs were isolated and scraped clean of all adhering muscle; rinsed in $70 \%$ ethanol, and followed by immersion for $30 \mathrm{sec}$ in Earle's or Hanks' Balanced Salt Solution (isotonic EBSS or HBSS). The ends of the femurs were removed and $5 \mathrm{ml}$ of medium were forced through the medullary canal to remove the marrow. This suspension was incubated at $25^{\circ} \mathrm{C}$ for $2-3$ days.

The medium of Doyle and Beckert (1970) was modified slightly. Medium 199, with HEPES buffer, was utilized since there was a better maintenance of optimal $\mathrm{pH}(7.2-7.3)$. The composition of the medium is as follows: 
Medium 199 with $25 \mathrm{mM}$ HEPES buffer, glutamine,

\section{Quantity (ml)}

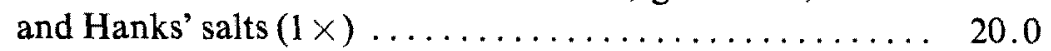

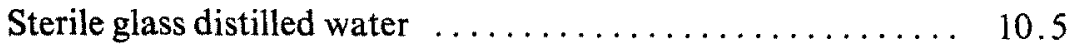

Fetal calf serum $\ldots \ldots \ldots \ldots \ldots \ldots \ldots \ldots \ldots \ldots \ldots \ldots$

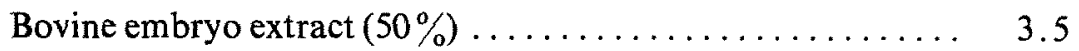

Penicillin-streptomycin $(5000 \mu / \mathrm{ml}-5000 \mathrm{mcg} / \mathrm{ml}) \ldots \ldots \ldots \quad 1.0$

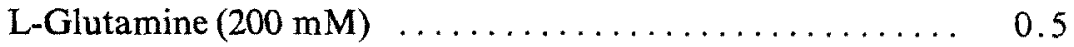

Fungizone $(250 \mathrm{mcg} / \mathrm{ml}) \ldots \ldots \ldots \ldots \ldots \ldots \ldots \ldots \ldots . \ldots . \ldots . \ldots$

Four hours prior to harvesting, each culture received $0.5 \mathrm{ml}$ of colcemid (10 $\mathrm{mcg} / \mathrm{ml}$ ) to yield a final concentration of $1 \mathrm{mcg} / \mathrm{ml}$ colcemid. The cultures were re-incubated for 4 hours. At the end of this period cultures were centrifuged for $800 \mathrm{rpm}$ in a Sorvall GLC-1 centrifuge for $6 \mathrm{~min}$. The supernatant was removed and the pellet re-suspended in $4 \mathrm{ml}$ isotonic HESS or EBSS for a brief washing. This was then recentrifuged. The pellet was re-suspended in $4 \mathrm{ml}$ of hypotonic HBSS or EBSS (5:1 dilution) for $10 \mathrm{~min}$. Following centrifugation, the pellet was re-suspended in $4 \mathrm{ml}$ of freshly prepared fixative (3:1, methanol-acetic acid) for $10 \mathrm{~min}$. This suspension was then centrifuged and re-suspended in fresh fixative for $20-30 \mathrm{~min}$. At the end of this period the cells were again centrifuged and the pellet re-suspended in about $0.5 \mathrm{ml}$ of the remaining volume. One drop of the fixed cell suspension was dropped onto precleaned, cold, wet (distilled water) slides from a height of about 4-5 inches. Slides were either air-dried or flame-dried, depending on the specific banding method studied.

The following banding methods were utilized in this investigation:

G-banding: Schnedl (1971), and modifications, such that the time of $0.07 \mathrm{~N}$ $\mathrm{NaOH}$ treatment was varied between $60-120 \mathrm{sec}$, and incubation in Sørenson buffer (pH 6.8) was varied from 1-2 days; Drets and Shaw (1971), and modifications, such that the time of $0.07 \mathrm{~N} \mathrm{NaOH}$ treatment was varied between $30-90 \mathrm{sec}$, and incubation in $12 \times \mathrm{SSC}$ (at $65^{\circ} \mathrm{C}$ ) was varied from 1-3 days; Utakoji (1972), and modified so that $\mathrm{KMnO}_{4}(10 \mathrm{mM})$ treatment was varied between $20-40 \mathrm{~min}$; Shiraishi and Yosida (1972), and modifications, such that the $8 \mathrm{M}$ urea treatment was varied between 10-40 min, and staining time was varied from 5-20 min; Sun et al. (1974); Wang and Federoff (1972), and modifications, such that the time of trypsin treatment was varied between $15 \mathrm{sec}-15 \mathrm{~min}$; Patil et al. (1971), and modifications, such that the time of staining in Giemsa 9 was varied between $1-5 \mathrm{~min}$, and $\mathrm{pH}$ of stain varied between $\mathrm{pH} 9.0-12.0$; Sumner et al. (1971), and modified so that the time of incubation in $2 \times \mathrm{SSC}$ (at $60^{\circ} \mathrm{C}$ ) was varied between $15-120 \mathrm{~min}$.

C-banding: Sumner (1972); Gallagher et al. (1973).

F-banding: Rodman (1974); Rodman and Tahiliani (1973), and modifications, such that the time in $0.14 \mathrm{M} \mathrm{Na}_{2} \mathrm{HPO}_{4}$ was varied between 5-20 min, and time in $12 \times \mathrm{SSC}$ (at $20^{\circ} \mathrm{C}$ ) was varied from 1-3 days.

Photomicrographs were taken with a Zeiss Photo-microscope using a green filter (No. 58) and Kodak High Contrast Copy Film. All prints were made on Agfageveart Rapidoprint Contrast 4 paper. 


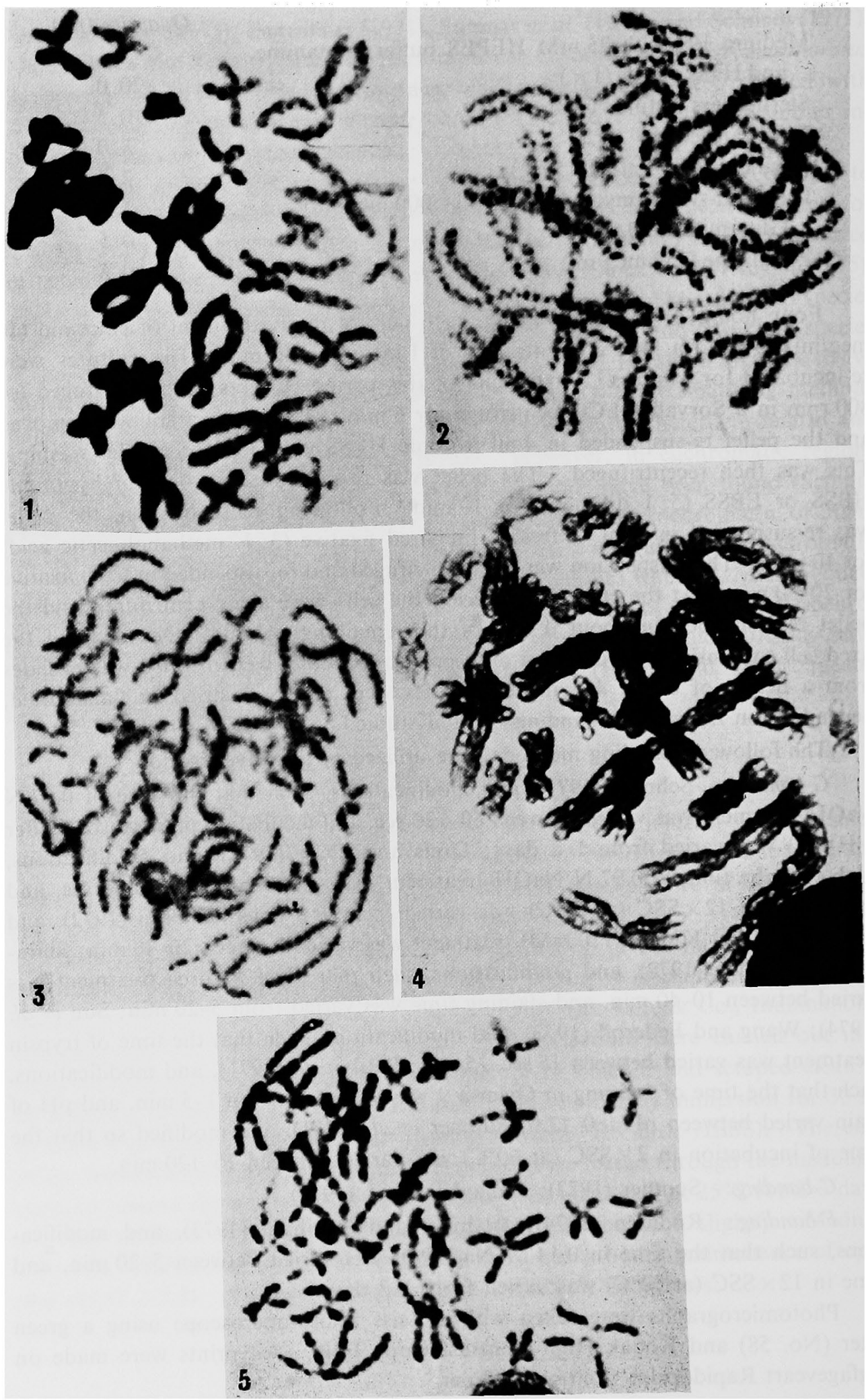




\section{Results}

Most of the methods employed yielded similar results in terms of chromosome appearance, i.e., uniformly spaced light and dark regions of a beadlike character.

The method of Schnedl (1971) yielded optimal results when chromosomes were exposed to $0.07 \mathrm{~N} \mathrm{NaOH}$ for $90 \mathrm{sec}$, incubated for $24 \mathrm{hr}$ in Sørenson buffer (pH 6.8), and stained in Giemsa for $40 \mathrm{~min}$. Since dotted regions correspond across both sister chromatids, there is a suggestion of banding in some of the chromosomes (Fig. 1).

The best results were obtained with the method of Rodman and Tahiliani (1973) when chromosomes were treated with $0.14 \mathrm{M} \mathrm{Na}_{2} \mathrm{HPO}_{4}$ for $15 \mathrm{~min}$, followed by incubation in $12 \times \mathrm{SSC}$ at $20^{\circ} \mathrm{C}$ for 2 days (Fig. 2). Once again note the prominent F-banded appearance of the chromosomes. C-banding of centromeric heterochromatin was elicited with this method using another modification which involved a 10 min incubation in $\mathrm{Na}_{2} \mathrm{HPO}_{4}$ followed by 2 days in $12 \times \mathrm{SSC}$.

The method of Patil et al. (1971) yielded optimal results when chromosomes were stained for $5 \mathrm{~min}$ in $\mathrm{pH}$ 9.0. The chromosomes showed a granulated appearance (Fig. 3).

The procedure of Wang and Federoff (1972) produced maximal results when chromosomes were exposed to $0.1 \%$ trypsin for $1 \mathrm{~min}$. Fig. 4 illustrates the typically bloated trypsin-treated chromosomes, with a suggestion of striated regions.

The most promising results using $8 \mathrm{M}$ urea (Shiraishi and Yosida 1972) were produced when treatement was for $10 \mathrm{~min}$, followed by staining in Giemsa for 15 min. Definite banding patterns were found in many of the chromosomes (Fig. 5).

All other methods of banding and modifications, as presented in the Mateials and methods section, produced unsatisfactory results.

There was no difference in banding patterns between male and female sexes.

\section{Discussion}

This work, utilizing several common banding methods (G-, F-, and C-banding) and their modifications, is the first report of banding of the chromosomes of Rana pipiens. Similar staining characteristics of the chromosomes have been elicited with diverse methods with the production of differential chromosome staining of a beadlike character. However, the methods utilized have not allowed satisfactory differentiation of different chromosomes within the complement.

Although extensive work has been reported for C-banding in various anuran families (Ruiz and Becak 1976, Raicu and Geormǎneanu 1977, Schmid 1978a, 1978b),

Figs. 1-5. 1, G-banding, Schnedl, 1971 (modified). Chromosomes were treated for $90 \mathrm{sec}$ in $0.07 \mathrm{~N} \mathrm{NaOH}$, incubated for $24 \mathrm{hr}$ in Sorenson buffer (pH 6.8), and stained with Giemsa for $40 \mathrm{~min}$. $($ Bar $=0.5 \mu \mathrm{m})$. 2, F-banding, Rodman and Tahiliani, 1973 (modified). Chromosomes were treated for $15 \mathrm{~min}$ in $0.14 \mathrm{M} \mathrm{Na}_{2} \mathrm{HPO}_{4}$, followed by incubation in $12 \times \mathrm{SSC}$ at $20^{\circ} \mathrm{C}$ for 2 days. $(\mathrm{Bar}=0.5 \mu \mathrm{m})$. 3, G-banding, Patil et al. 1971 (modified). Chromosomes were stained for $5 \mathrm{~min}$ at $\mathrm{pH}$ 9.0. $(\mathrm{Bar}=0.5 \mu \mathrm{m})$. 4, Trypsin method of Wang and Federoff, 1972 (modified). Chromosomes were treated for $1 \mathrm{~min}$ in $0.1 \% \operatorname{trypsin}(\mathrm{Bar}=0.5 \mu \mathrm{m})$. 5, G-banding, Shiraishi and Yosida, 1972 (modified). Chromosomes were treated for $10 \mathrm{~min}$ in $8 \mathrm{M}$ urea, followed by staining with Giemsa for $15 \mathrm{~min}$. $(\mathrm{Bar}=0.5 \mu \mathrm{m})$. 
only the chromosomes of Xenopus muelleri have been G-banded (Stock and Mengden 1975), and the latter G-banding was only of certain chromosomes and not the entire complement. It has been suggested that the extreme contraction of anuran metaphase chromosomes may be the explanation for the lack of the characteristic Q- and G-bands, (Schmid 1978a, 1978b). This is supported by the fact that the mean DNA content per $\mu \mathrm{m}$ of chromosome length of metaphase chromosomes is 1.5-3.0 times greater in bufonids, hylids, and other anuran species (Schmid 1978a). However, perhaps it is very significant that a major difference between members of the Urodela (which are more readily banded) and the Anura (which apparently are less easily banded) exists in terms of nuclear DNA content, with nuclear DNA of Anura being markedly less than that found in Urodela. Studies on several members of the family Ranidae have shown a DNA content of $6.6-15.8 \mathrm{pg} /$ nucleus, while the DNA content of the members of the family Salamandridae (order Urodela) is $28.0-98.0 \mathrm{pg} /$ nucleus (Chiarelli and Capanna 1973). It is conceivable that both nuclear DNA content and DNA content/chromosome length ratios may explain banding difficulties in anurans. Nevertheless, this inference does not seem to hold for Xenopus muelleri (family: Pipidae) which has a comparable DNA content as Ranidae, but yet can be banded satisfactorily.

There have been a number of theories or explanations proposed on the mechanisms involved in chromosome banding. One explanation of banding proposed was an accentuation of a pre-existing distribution of DNA and associated chromatin components (Rodman and Tahiliani 1973). A bimodal mechanism has been proposed which states that positive bands are due to precipitation of a selective group of chromatin proteins with a condensation of their associated DNA, while negative bands are due to a loss or displacement of protein with concomitant relaxation and stretching of DNA (Rodman 1974). It has also been suggested that the specific non-histones of positive regions render such regions more resistant to dispersion than interband regions (Burkholder 1975). Sumner and Evans (1973) reported that Giemsa is attached to DNA molecules at two separate points which are brought into close proximity by the folding of DNA. The spatial arrangement of dye-binding sites in the chromosomes is influenced by non-histone proteins, and the positive bands are due to binding of the dye in regions with specific non-histone proteins. It has been shown that an uneven extraction of acid-insoluble non-histone protein occurs during various G-banding procedures, such that a correspondence was observed between dansyl-Cl fluorescent-stained regions obtained after Giemsa pre-treatments and normal G-banded chromosomes (Matsukuma and Utakoji 1976). It is suggested that perhaps there is a variation in different nonhistone proteins along the chromosomes so that banding is produced differentially. Further work must be undertaken to elucidate whether such an intrachromosomal variation of non-histone molecular species does indeed exist along the chromosomes.

It is concluded that perhaps in the chromosomes of Rana pipiens various physical and chemical reasons exist for the phenomenon of the beaded differential chromosome staining elicited. Further studies are being undertaken to clarify whether or not different modifications of present banding methods or different methods may produce more distinctive banding patterns in Rana pipiens and other Anura. 


\section{Abstract}

Differential chromosome staining has been obtained for the chromosomes of cultured bone marrow cells of Rana pipiens. Although a wide variety of methods were investigated, only certain banding methods and modifications thereof gave promising results of particular significance for further investigation.

\section{Acknowledgments}

We thank Mr. Leo Barraco (Majestic Photo, Richmond Hill, New York) and James V. Manago for their technical assistance in photography.

\section{References}

Arrighi, F. E., and Hsu, T. C. 1971. Localization of heterochromatin in human chromosomes. Cytogenetics 10: 81-86.

Bailly, S. 1972. Etude de la fluorescence des chromosomes mitotiques de Pleurodeles walthii Michah., après coloration par la moutarde de quinacrine. C. R. Acad. Sci. (Paris) 275: $1267-1270$.

- 1976. Localisation et signification des zones $Q$ observées sur les chromosomes mitotiques de l'Amphibien Pleurodeles waltlii Michah, après coloration par la moutarde de quinacrine. Chromosoma (Berl.) 54: 61-68.

-Guillemin, C. and Labrousse, M. 1973. Comparison du nombre et de la position des zones spécifiques révélées sur les chromosomes mitotiques de l'Amphibien Urodèle Pleurodeles waltiii Michah, par les techniques de coloration au colorant de Giemsa et à la moutarde de quinacrine. C. R. Acad. Sci. (Paris) 276: 1867-1869.

Batistoni, R., Nardi, I and Pilone, G. B. 1974. Banding patterns on lampbrush chromosomes of Triturus marmoratus (Amphibia Urodela) by the Giemsa Stain. Chromosoma (Berl.) 49: 121-134.

Beckert, W. H. and Doyle, W. 1967. Anuran karyotype methodology I. The karyotype of Bufo marinus. Canad. Genet. Cytol. 9:297-301.

Burkholder, G. D. 1975. The ultrastructure of G- and C-banded chromosomes. Exp. Cell Res. 90: 269-278.

Caspersson, T., Farbar, S., Foley, G. E., Kudynowski, J., Modest, E. J., Simonsson, E., Wagh, U. and Zech, L. 1968. Chemical differentiation along metaphase chromosomes. Exp. Cell Res. 49: 219-222.

-, Zech, L., Johansson, C. and Modest, E. J. 1970. Identification of human chromosomes by DNA-binding fluorescent agents. Chromosoma (Berl.) 30: 215-227.

-, - and Modest, E. J. 1970. Fluorescent labeling of chromosome DNA: Superiority of quinacrine mustard to quinacrine. Science 170: 762.

-, -, Modest, E. J., Foley, G. E., Wagh, U. and Simonsson, E. 1969. Chemical differentiation with fluorescent alkylating agents in Vicia faba metaphase chromosomes. Exp. Cell Res. 58: $128-140$.

Doyle, W. and Beckert, W. H. 1970. Chromosome characteristics of the Bufonidae among species and within populations. Caryologia 23: 143-154.

Drets, M. E. and Shaw, W. W. 1971. Specific banding patterns of human chromosomes. Proc. nat. Acad. Sci. (Wash.) 68: 2073-2077.

Dutrillaux, B. deGrouchy, J. and Finaz, C. 1971. Mise en évidence de la structure fine des chrosomes humains par digestion enzymatique (pronase en particulier). C. R. Acad. Sci. (Paris) 273: 587-588.

- and Lejeune, J. 1971. Sur une novelle technique d'analyse du caryotype humains. C. R. Acad. Sci. (Paris) 272: 2638-2640. 
Gagne, R., Tanguay, R. and Laberge, C. 1971. Differential staining patterns of heterochromatin in man. Nature (Lond.) 232: 29-30.

Gallagher, A., Hewitt, G. and Gibson, I. 1973. Differential Giemsa staining of heterochromatic B-chromosomes in Myrmeleotettix maculatus (Thumb.) (Orthoptera: Acrididae). Chromosoma (Berl.) 40: 167-172.

Hsu, T. C., Pathak, S. and Shafer, D. A. 1973. Induction of chromosomes crossbanding by treating cells with chemical agents before fixation. Exp. Cell Res. 79: 484-487.

Labrousse, M., Guillemin, C. and Gallien, L. 1972. Mise en évidence sur les chromosomes de l'Amphibien Pleurodeles waltlii Michah., de secteurs d'affinité différente pour le colorant de Giemsa à pH 9. C.R. Acad. Sci. (Paris) 274: 1063-1065.

Mancino, G., Ragghianti, M. and Innocenti, M. 1973. I cariotipi di Triturus marmoratus e $T$. cristatus studiati con il "C-staining method." Atti Accad. naz. Lincei Rc. Ser. 8, 55: $559-564$.

Matsukuma, S. and Utakoji, T. 1976. Uneven extraction of protein in Chinese hamster chromosomes during G-staining procedures. Exp. Cell Res. 97: 297-303.

Meisner, L. F., Chuprevich, T. W., Johnson, C. B., Inhorn, S. L. and Carter, J. J. 1973. Banding of human chromosomes with caesium chloride. The Lancet $1: 100-101$.

Miller, D. A., Allerdice, P. W. and Miller, O. J. 1971. Quinacrine fluorescence patterns of human D group chromosomes. Nature 232: 24-27.

Morescalchi, A. 1974. Role of the variations in nuclear DNA on the karyological differentiation. In: Cytotaxonomy and Vertebrate Evolution (A. B. Chiarelli and E. Capanna, eds.), pp. 233-348. New York: Academic Press, Inc.

Nardi, I. Ragghianti and M. Mancino, G. 1973. Banding patterns in newt chromosomes by the Giemsa stain. Chromosoma (Berl.) 40: 321-331.

Patil, S. R., Merrick, S. and Lubs, H. A. 1971. Identification of each human chromosome with a modified Giemsa stain. Science 173: 821-822.

Ragghianti, M., Innocenti, S. B. and Mancino, G. 1973. Bandeggiatura indotta da "C-, G-, ə Q-staining methods" e pattern di replicazione dei cromosomi di Triturus. Atti. Accad. nzz. Lincei Rc. Ser. 8, 55: 764-770.

Raicu, P. and Geormăneanu, C. 1977. Constitutive heterochromatin in Rana ridibunda. J. Heredity $68: 343-344$.

Rodman, T. C. 1974. Human chromosome staining by the Feulgen stain aids in localizing classes of chromatin. Science 184: 171-173.

- and Tahiliani, S. 1973. The Feulgen banded karyotype of the mouse. Chromosoma (Berl.) 42: 37-56.

Rudak, E. and Callan, H. G. 1976. Differential staining and chromatin packing of the mitotic chromosomes of the newt Triturus cristatus. Chromosoma (Berl.) 56: 349-362.

Ruiz, I. R. G. and Becak, W. 1976. Further studies on polyploid amphibians V. C-banding in diploid and tetraploid species of Odontophrynus. Chromosoma (Berl.) 54: 69-74.

Schmid, M. 1978a. Chromosome banding in Amphibia I. Constitutive heterochromatin and nucleolus organizer regions in Bufo and Hyla. Chromosoma (Berl.) 66: 361-388.

- 1978b. Chromosome banding in Amphibia II. Constitutive heterochromatin and nucleolus organizer regions in Ranidae, Microhylidae, and Rhacophoridae. Chromosoma (Berl.) 68: $131-148$.

Schnedl, W. 1971. Analysis of the human karyotype using a reassociation technique. Chromosoma (Berl.) 34: 448-454.

Seabright, M. 1972. The use of proteolytic enzymes for the mapping of structural rearrangements in the chromosomes of man. Chromosoma (Berl.) 36: 204-210.

Shiraishi, Y. and Yosida, T. H. 1972. Banding pattern analysis of human chromosomes by use of a urea technique. Chromosoma (Berl.) 37: 75-83.

Stock, A. D. and Mengden, G. A. 1975. Chromosome banding pattern conservatism in birds and nonhomology of chromosome banding patterns between birds, turtles, snakes, and amphibians. Chromosoma (Berl.) 50: 69-77. 
Sumner, A. T. 1972. A simple technique for demonstrating centromeric heterochromatin. Exp. Cell Res. 75: 304-306.

- and Evans, H. J. 1973. Mechanisms involved in the banding of chromosomes with quinacrine and Giemsa II. The interaction of the dyes with the chromosomal components. Exp. Cell Res. 81 : 221-236.

-, Evans, H. J. and Buckland, R. A. 1971. New technique for distinguishing between human chromosomes. Nature (Lond.) 232: 31-32.

Sun, N. C., Chu, E. H. Y. and Chang, C. C. 1974 . Staining method for the banding patterns of human mitotic chromosomes. Caryologia 27 : 315-324.

Utakoji, T. 1972. Differential staining patterns of human chromosomes treated with potassium permanganate. Nature (Lond.) 239: 168-170.

Verma, R. S. and Lubs, H. A. 1975. A simple R-banding Technic. Amer. J. hum. Genet. 27: $110-117$.

- and Lubs, H. A. 1976. Additional observations on the preparation of R-banded chromosomes with acridine orange. Canad. J. Genet. and Cytol. 18: 45-50.

Wang, H. C. and Federoff, S. 1972. Banding in human chromosomes treated with trypsin. Nature (Lond.) 235: 52-53. 